Domahidi, Z., J. Shonfield, S. E. Nielsen, J. R. Spence, and E. M. Bayne. 2019. Spatial distribution of the Boreal Owl and Northern Saw-whet Owl in the Boreal region of Alberta, Canada. Avian Conservation and Ecology 14(2):14. https://doi.org/10.5751/ACE-01445-140214

Copyright $(C) 2019$ by the author(s). Published here under license by the Resilience Alliance.

Research Paper

\title{
Spatial distribution of the Boreal Owl and Northern Saw-whet Owl in the Boreal region of Alberta, Canada
}

\author{
Zoltan Domahidi $^{1}$, Julia Shonfield ${ }^{2}$, Scott E. Nielsen ${ }^{1}$, John R. Spence ${ }^{1}$ and Erin M. Bayne ${ }^{2}$ \\ ${ }^{1}$ Department of Renewable Resources, University of Alberta, ${ }^{2}$ Department of Biological Sciences, University of Alberta
}

\begin{abstract}
Understanding what factors influence the occurrence and distribution across the landscape is necessary for species conservation and management. Distribution data for many owl species are inadequate because of their nocturnal behavior and cryptic nature. We examined the role of climate, land cover, and human disturbance in shaping spatial distribution of the Boreal Owl (Aegolius funereus) and Northern Saw-whet Owl (Aegolius acadicus) in northern Alberta. Using autonomous recording units, we conducted passive acoustic surveys to detect owls of both species throughout Alberta's boreal forest. We compiled data on environmental variables at each sample site corresponding to a local scale and at landscape scale. A boosted regression tree analysis identified average minimum winter temperature as the most important predictor of Boreal Owl distribution. Boreal Owls were more likely to be present in cool environments with cold winters, and a low percentage of grassland cover at the landscape scale. Cropland cover at the local scale was the most influential factor in the final distribution model for the Northern Saw-whet Owl, and they were more likely to be present in areas where cropland was interspersed with deciduous-dominated forests. Furthermore, these areas generally had cool summer temperatures and received less precipitation as snow. Linear features at the landscape scale negatively influenced distribution of Boreal Owls, but edges created by linear features at local scale positively influenced Northern Saw-whet Owl distribution. Our study provides new information about habitat use that can be applied in management and conservation of these two poorly studied species of owls.
\end{abstract}

\section{Répartition de la Nyctale de Tengmalm et de la Petite Nyctale dans la région boréale de l'Alberta, Canada}

RÉSUMÉ. Pour bien conserver et gérer les espèces, il faut comprendre quels facteurs agissent sur leur présence et leur répartition dans le paysage. Les données de répartition de nombreuses espèces de chouettes sont inadéquates en raison de leur comportement nocturne et de leur nature cryptique. Nous avons examiné le rôle du climat, de la composition du paysage et des perturbations d'origine humaine dans le façonnement de la répartition spatiale de la Nyctale de Tengmalm (Aegolius funereus) et de la Petite Nyctale (Aegolius acadicus) dans le nord de l'Alberta. Au moyen d'enregistreurs automatisés, nous avons effectué des relevés acoustiques passifs afin de détecter les individus des deux espèces de nyctales en forêt boréale albertaine. Nous avons compilé les valeurs de variables environnementales récoltées à chaque site d'échantillonnage aux échelles locale et du paysage. Une analyse de régression arborescente par entrée forcée a permis de déterminer que la température hivernale minimum moyenne était la valeur explicative la plus importante dans la répartition de la Nyctale de Tengmalm. Les Nyctales de Tengmalm étaient plus susceptibles d'être présentes dans des environnements frais aux hivers froids, et ayant une faible superficie de prairies à l'échelle du paysage. La superficie de terres cultivées à l'échelle locale était le facteur ayant le plus d'effet dans le modèle final de répartition pour la Petite Nyctale, et les individus étaient plus susceptibles d'être présents aux endroits où les terres cultivées voisinaient des forêts à dominance de feuillus. De plus, ces endroits avaient généralement des températures estivales fraiches et recevaient moins de précipitation sous forme de neige. Les caractéristiques linéaires à l'échelle du paysage influaient négativement la répartition des Nyctales de Tengmalm, mais les bordures créées par ces mêmes caractéristiques à l'échelle locale influaient positivement la répartition des Petites Nyctales. Nos résultats fournissent de nouvelles informations sur l'utilisation de l'habitat qui peuvent être appliquées dans la gestion et la conservation de ces deux espèces de chouettes peu étudiées.

Key Words: acoustic data; agriculture; boosted regression trees; Boreal Owl; Canadian boreal; distribution; linear features; Northern Saw-whet Owl

\section{INTRODUCTION}

Understanding where species occur, and why individuals occur in some areas but not others, is essential for developing conservation or management plans, especially for rare (Rabinowitz 1981) or endangered taxa (Rushton et al. 2004, Muñoz et al. 2005, Guisan et al. 2013, Harms et al. 2017). Spatial distribution of a species is largely shaped by environmental heterogeneity, including variation in climate, land cover, natural disturbance history, and biotic interactions, together with constraints provided by species dispersal ability (MacArthur 1972, Block and Brennan 1993, Castro et al. 2008, Chen et al. 2011). Although ranges are often observed at national or continental scales, species distributions are scale dependent (Lehmkuhl and Raphael 1993, Scholer et al. 2014) and the apparent main drivers can change with spatial resolution (López-López et al. 2006, Muñoz and Real 2013, Di Vittori and López-López 2014). Nonetheless, distribution of a 
particular species is frequently explained in relation to land cover variables collected at a local scale, where the habitat is more homogeneous (Muñoz and Real 2013).

Two of the most common issues in studies of spatial distributions are where to sample the target species and what environmental data to collect (Rushton et al. 2004). Sound knowledge of species distribution is limited to surveyed areas. Studies of wide-ranging, unevenly distributed, rare, or cryptic species are especially problematic because records are often concentrated in small areas or widely dispersed as a result of low sampling effort over large areas. Because it is impractical to allocate survey effort evenly across entire regions, researchers model spatial distribution to predict species occurrence for conservation planning and wildlife management (Buckland and Elston 1993). Indeed, advances in survey techniques, statistical modeling, and increased use of geographic information systems (Osborne et al. 2001, Elith et al. 2006, Young et al. 2012) are providing more precise predictions of species distributions (Campos-Cerqueira and Aide 2016, Shonfield and Bayne 2017a). Recently, the use of machine learning techniques in ecology, such as classification and regression trees, supports identification of complex relationships or patterns between predictor and response variables, in addition to increasing accuracy of predictions (De'ath and Fabricius 2000, De'ath 2007, Elith et al. 2008). These techniques are especially valuable for the study of rare species found in remote areas, where obtaining large enough sample sizes for modeling and statistical analysis is problematic but for which knowledge of distribution is especially critical for conservation (Mi et al. 2014, 2017).

Despite having large estimated populations and large ranges, which can span multiple states/provinces or even continents, data for many owl species are inadequate. Attempts to estimate population size and distribution rely mainly on national programs like the Raptor Grid in Finland (Saurola 2009), and the Breeding Bird Survey (Sauer et al. 2013) and Christmas Bird Count (Dunn et al. 2005) in North America, which have been developed for monitoring multiple avian species. However, such surveys are not satisfactory for birds of prey like owls because they fail to capture species breeding in remote areas or are not conducted at the appropriate season or time of day to correctly estimate breeding populations (Kirk and Hyslop 1998, Saurola 2009). In North America, studies of owl habitat use are predominantly focused on species at risk, such as the Burrowing Owl (Athene cunicularia) in the Canadian prairies (Haug and Oliphant 1990) and the Northern Spotted Owl (Strix occidentalis) in the Pacific Northwest of North America (Carey et al. 1990, Lehmkuhl and Raphael 1993, Folliard et al. 2000). Many other owl species remain understudied and, as a result, their conservation status is based on limited data.

Boreal Owls (Aegolius funereus) and Northern Saw-whet Owls (Aegolius acadicus) are two such species. Both are small, nocturnal owls, with widespread and uneven distributions across North America (Johnsgard 2002). Results of local studies suggest considerable variation in the land-cover types they use. For example, in Colorado USA, Boreal Owls inhabit high-elevation mature conifer forests (Palmer 1987) while in the Northern Rocky Mountains, USA, they used both conifer and aspen stands (Hayward et al. 1993, Hayward 1997). Northern Saw-whet Owls were found in mainly forested areas that included open canopy components at a local (20 ha) scale in the Sierra Nevada, California, USA (Groce and Morrison 2010) while on Haida Gwaii, British Columbia, many were found in landscapes containing a mixture of old and young forests (Gill and Cannings 1997). In central Alberta, they occupied landscapes that were more connected and characterized by a wide range (16-100\%) of forest cover (Grossman et al. 2008, Hinam and St. Clair 2008). Although both owl species are included in the Canadian Landbird Monitoring Strategy, published information about distribution and habitat use of Boreal Owls in Canada is lacking, and for Northern Saw-whet owls the information is sparse.

Major landscape changes are occurring in the boreal forest of Alberta, but factors associated with habitat use and distribution of these two small owl species in this region have not been studied in detail. Thus, more specific information is required to support decision making and effective conservation programs for these elements of the biota. In this study we used acoustic recordings from autonomous recording units (ARUs) to document occurrence of Boreal and Northern Saw-whet Owls in the Boreal Forest Natural Region of Alberta during the breeding season. Our primary goal was to explore the capacity of climate, biotic, landscape, and forest disturbance variables to predict owl occurrence at two spatial scales. We used models developed in the context of this work to predict the spatial distribution of Boreal and Northern Saw-whet Owls and generate distribution maps for Alberta's boreal region.

\section{METHODS}

\section{Study area}

The Boreal Forest Natural Region of Alberta is the largest natural region of the province, spanning over $381,046 \mathrm{~km}^{2}$ (Fig. 1). Undulating forested plains and extensive wetlands dominate this region, with elevations ranging from $150 \mathrm{~m}$ at the AlbertaNorthwest Territories border to $1100 \mathrm{~m}$ near the Alberta-British Columbia border (Natural Regions Committee 2006). The climate is characterized by short, cool summers and long, cold winters, with a $5{ }^{\circ} \mathrm{C}$ temperature difference in mean annual temperature between the warmest and coldest parts of the region (Natural Regions Committee 2006). Most of the precipitation falls between April and August, with average annual precipitation ranging between 377 and $535 \mathrm{~mm}$ (Natural Regions Committee 2006).

Deciduous, mixed, and coniferous forest interspersed with wetlands dominate the upland areas. However, nearly half of the area with sufficient soil and growing season has been converted to cultivate mainly barley and forage crops (Natural Regions Committee 2006). In the remaining forested area, trembling aspen (Populus tremuloides) and balsam poplar (Populus balsamifera) are the dominant broadleaf tree species, while conifer species include tamarack (Larix laricina), white spruce (Picea glauca), and black spruce (Picea mariana) in moist areas, and lodgepole pine (Pinus contorta) and jack pine (Pinus banksiana) in drier areas (Natural Regions Committee 2006). Forestry operations are conducted throughout the region, and natural gas and oil exploration/extraction may be locally intensive. 
Fig. 1. Map of survey sites $(\mathrm{n}=677)$ within the Boreal Forest Natural Region of Alberta, Canada. Autonomous recording units (ARUs) were deployed in two grid systems: (1) grids of five ARUs, with one unit at the corners of a 1600-m square and one central unit ( $n=69)$, and (2) four-unit grids with one ARU at each corner of a $600-\mathrm{m}$ square $(n=83)$.

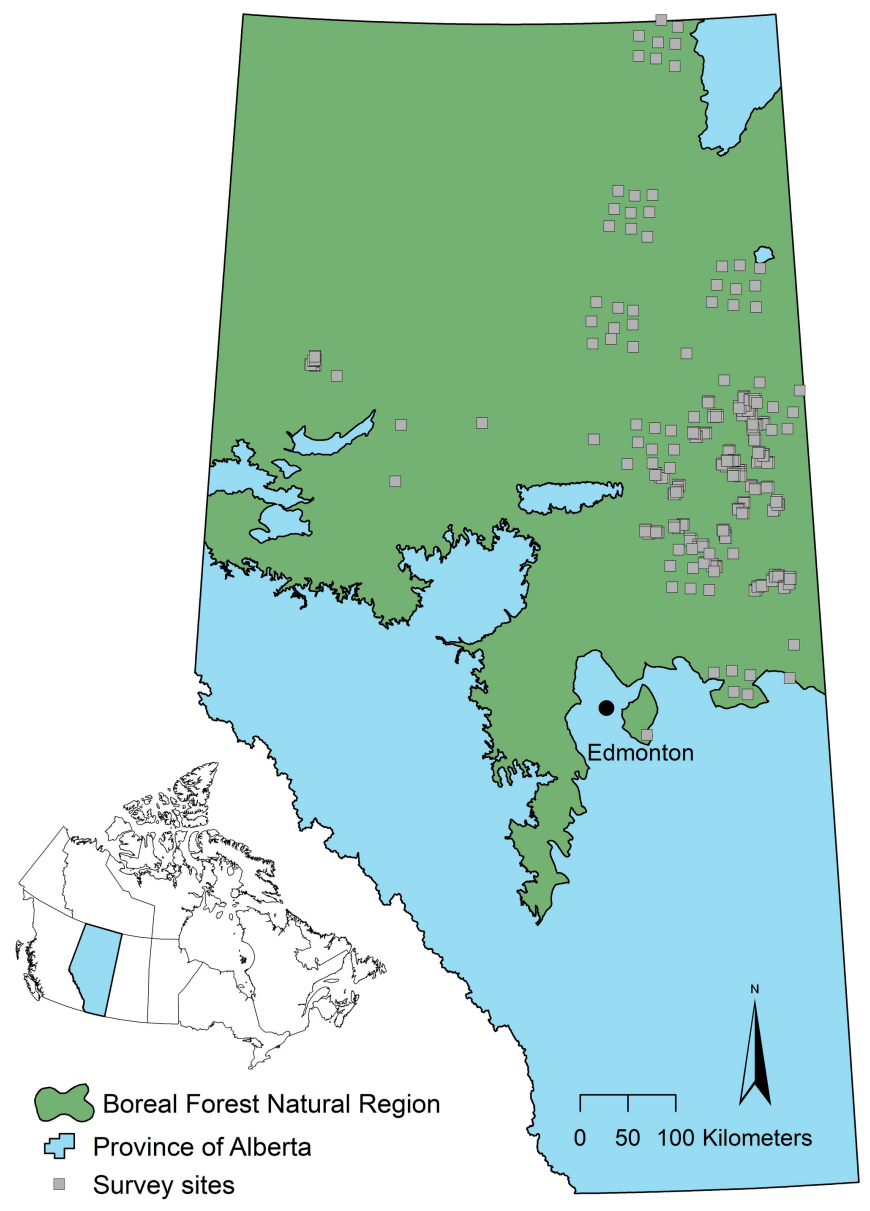

\section{Acoustic data}

Nocturnal owl surveys using point count protocols and broadcast of owl calls to elicit responses of conspecifics have been traditionally used to study owls (Takats et al. 2001); however, such surveys may be biased by drawing owls into otherwise unused areas as a reaction to call broadcasts (Kissling et al. 2010). Here we used passive acoustic monitoring that has numerous advantages over traditional surveys (reviewed by Shonfield and Bayne 2017a), including sampling over longer time scales and providing permanent acoustic records that can be reanalyzed to answer additional questions (Campos-Cerqueira and Aide 2016). Furthermore, although higher local detection probabilities are associated with call broadcast surveys (Zuberogoitia et al. 2011), passive acoustic monitoring provides more survey opportunities through numerous scheduled audio recordings (Shonfield and Bayne 2017a).
During 2013-2016 we deployed SM2+ Song Meters (Wildlife Acoustics, Inc., Maynard, Massachusetts, USA), placed in grids throughout the study area (Fig. 1) to detect the species of interest (Boreal and Northern Saw-whet Owls, Great Horned Owls [Bubo virginianus] as potential predators, and Pileated Woodpeckers [Dryocopus pileatus] as potential facilitators). Data from these recording units were intended to answer multiple questions for various bird species, and so to accommodate differences in landscape size and call detectability of a multispecies survey we used two grid types. First, we set up 69 grids of five ARUs, with one unit at the corners of a 1600-m square and one central unit, and second, we deployed 83 four-unit grids with one ARU at each corner of a 600-m square. We used 332 ARUs placed in systematic grids used for continuous acoustic monitoring by the Alberta Biodiversity Monitoring Institute, while we deployed an additional 345 units in predominantly forested environments considered suitable for cavity nesting owls. We programmed the units to record 10 minutes every hour for at least two weeks between mid-March and mid-May, when owls are actively vocalizing to attract mates and defend their breeding territories. We considered the location of each ARU an independent survey site and assumed that the presence of a species was evidence that the site contains at least some elements necessary for breeding and survival (Block and Brennan 1993).

We used Song Scope (Wildlife Acoustics, Inc., Maynard, Massachusetts, USA) to build automated species recognition algorithms (hereafter referred to as "recognizers"), to process recordings and identify vocalizations of the target species. Separate recognizers were used to detect the staccato song of the Boreal Owl (Bondrup-Nielsen 1984), the advertising call of the Northern Saw-whet Owl (Rasmussen et al. 2008), the territorial hoot of the Great Horned Owl (Kinstler 2009), and the longdistance drumming, "cackle" and "wuk" calls of Pileated Woodpeckers (Tremain et al. 2008). The recognizers for the Boreal Owl and Great Horned Owl have been tested for their utility in detecting these species (Shonfield et al. 2018), and previously used to determine their occurrence in northern Alberta (Shonfield and Bayne 2017b). The Northern Saw-whet Owl and Pileated Woodpecker recognizers were built using the same process described in Shonfield et al. (2018). Because recognizers are not completely accurate in detecting the target species (Shonfield et al. 2018), a trained listener (ZD) checked the computer output for Type I errors, i.e., false positives that were not the call of the target species, and validated the list of records until the first confirmed detection at each location.

\section{Predictor variables}

We chose an initial set of 38 potential predictor variables (Table 1) to investigate the capacity of climate, landscape characteristics, and biological factors to predict owl occurrence. Temperature and precipitation, different landscape variables, and presence of nesting facilitators, competitors, or potential predators have all been identified as factors influencing geographical distribution of species, including owls. Although some of the variables might seem unrelated to the ecology of owls, the use of indirect variables for the purpose of prediction of species distribution is both practical and feasible (Castro et al. 2008). Most of the biologically meaningful variables are difficult, if not impossible, to estimate/ 
Table 1. Predictor variables used to model spatial distribution of Boreal (Aegolius funereus) and Northern Saw-whet Owls (Aegolius acadicus) in the Boreal Forest Natural Region of Alberta, Canada. Presence/absence data on bird species occurrence was determined from acoustic recordings, climate data was calculated for each survey site using ABClimate software, while landcover and human disturbance variables were calculated from the Alberta Biodiversity Monitoring Institute's georeferenced data layers.

\begin{tabular}{|c|c|c|c|c|}
\hline Code & Variable & Range & Variable type & Scale \\
\hline boow & Presence / absence of Boreal Owl & - & Biotic & - \\
\hline ghow & Presence / absence of Great Horned Owl & - & Biotic & - \\
\hline nswo & Presence / absence of Northern Saw-whet Owl & - & Biotic & - \\
\hline piwo & Presence / absence of Pileated Woodpecker & _ & Biotic & - \\
\hline $\operatorname{con} 150$ & Percent coniferous forest & $0-100$ & Landscape & Local \\
\hline $\operatorname{con} 564$ & Percent coniferous forest & $0-100$ & Landscape & Landscape \\
\hline cro 150 & Percent cropland & $0-100$ & Landscape & Local \\
\hline cro564 & Percent cropland & $0-91$ & Landscape & Landscape \\
\hline $\operatorname{dec} 150$ & Percent deciduous forest & $0-100$ & Landscape & Local \\
\hline $\operatorname{dec} 564$ & Percent deciduous forest & $0-100$ & Landscape & Landscape \\
\hline for 150 & Percent forest cover & $0-100$ & Landscape & Local \\
\hline for564 & Percent forest cover & $0-100$ & Landscape & Landscape \\
\hline gra150 & Percent grassland cover & $0-100$ & Landscape & Local \\
\hline gra564 & Percent grassland cover & $0-96$ & Landscape & Landscape \\
\hline $\operatorname{mix} 150$ & Percent mixed wood forest & $0-100$ & Landscape & Local \\
\hline $\operatorname{mix} 564$ & Percent mixed wood forest & $0-72$ & Landscape & Landscape \\
\hline $\operatorname{shr} 150$ & Percent shrubland cover & $0-100$ & Landscape & Local \\
\hline $\operatorname{shr} 564$ & Percent shrubland cover & $0-100$ & Landscape & Landscape \\
\hline wat 150 & Percent water cover & $0-80$ & Landscape & Local \\
\hline wat564 & Percent water cover & $0-95$ & Landscape & Landscape \\
\hline hrdlin 150 & Percent hard linear features ${ }^{\dagger}$ & $0-24$ & Disturbance & Local \\
\hline hrdlin 564 & Percent hard linear features ${ }^{\dagger}$ & $0-8$ & Disturbance & Landscape \\
\hline ind 150 & Percent industrial disturbances ${ }^{\ddagger}$ & $0-100$ & Disturbance & Local \\
\hline ind564 & Percent industrial disturbances ${ }^{\ddagger}$ & $0-84$ & Disturbance & Landscape \\
\hline sftlin 150 & Percent soft linear features $\S$ & $0-55$ & Disturbance & Local \\
\hline sftlin564 & Percent soft linear features ${ }^{\S}$ & $0-19$ & Disturbance & Landscape \\
\hline ffp & Frost-free period & $92-109$ & Climate & - \\
\hline map & Mean annual precipitation ( $\mathrm{mm})$, & $314-570$ & Climate & - \\
\hline mat & Mean annual temperature $\left({ }^{\circ} \mathrm{C}\right)$ & $-2.2--1.8$ & Climate & - \\
\hline $\mathrm{mcmt}$ & Mean coldest month temperature $\left({ }^{\circ} \mathrm{C}\right)$ & $-23.8--15.5$ & Climate & - \\
\hline mwmt & Mean warmest month temperature $\left({ }^{\circ} \mathrm{C}\right)$ & $14.5-17.4$ & Climate & - \\
\hline pas & Precipitation as snow $(\mathrm{mm})$ & $97-164$ & Climate & - \\
\hline pptsm & Summer precipitation $(\mathrm{mm})$ & $138-284$ & Climate & - \\
\hline pptwt & Winter precipitation $(\mathrm{mm})$ & $44-79$ & Climate & - \\
\hline tavsm & Summer mean temperature $\left({ }^{\circ} \mathrm{C}\right)$ & $13-16$ & Climate & - \\
\hline tavwt & Winter mean temperature $\left({ }^{\circ} \mathrm{C}\right)$ & $-21.4--13.4$ & Climate & - \\
\hline td & Temperature difference between mwmt and $\mathrm{mcmt}\left({ }^{\circ} \mathrm{C}\right)$ & $31.4-40.4$ & Climate & - \\
\hline tmnwt & Winter mean minimum temperature $\left({ }^{\circ} \mathrm{C}\right)$ & $-25.4--18.7$ & Climate & - \\
\hline tmxsm & Summer mean maximum temperature $\left({ }^{\circ} \mathrm{C}\right)$ & $18.4-22.2$ & Climate & - \\
\hline
\end{tabular}

measure over large and remote areas while the predictor variables used by us are readily available from georeferenced datasets. In addition, the use of the machine learning approach in data analysis allowed us the liberal inclusion of variables without compromising predictive power of the final models.

For each surveyed location we compiled climatic variables using the ClimateAB software package (Government of Alberta, Alberta Sustainable Resource Development) that calculates values from climate grids based on monthly, annual, decadal, and 30-year normal climate data collected between 1901-2006 at standard weather stations across Alberta (Mbogga et al. 2010). We extracted landscape and human disturbance variables from the Alberta Biodiversity Monitoring Institute's Wall-to-Wall Land Cover Map Version 2.1 and Human Footprint Inventory
2014 Version 3 (https://abmi.ca/home/data-analytics/da-top/daproduct-overview/Human-Footprint-Products/HF-inventory.html). Each dominant forest cover type was quantified as percentage of total forested area. We compiled landscape and disturbance variables at two scales, based on a radius around the location of each unit: (1) the local scale at a $150-\mathrm{m}$ radius, and (2) the landscape scale at a $564-\mathrm{m}$ radius. We did this by drawing concentric buffers around each ARU location in ArcMap 10.4.1 (Environmental Systems Research Institute, Inc., Redlands, California, USA), and calculating percent area of the buffer covered by each landscape and disturbance type. Male Boreal Owls consistently vocalize within $100 \mathrm{~m}$ of potential nest sites (Hayward et al. 1993), defining a three-hectare local area. Using this information, and without knowing the exact location of a 
nest, we assumed that the local scale ( $7 \mathrm{ha}$ ) was reasonable to describe habitat associations in the immediate vicinity of our sites while maintaining the spatial separation of observation sites. Average home range size of Northern Saw-whet Owls in Alberta was reported at 89.4 ha with a range of 11.7 - 137.0 ha (Hinam and St. Clair 2008), which is about half the area of Boreal Owl home ranges in Fennoscandia at 150 to 230 ha (Korpimäki and Hakkarainen 2012). We chose to define the landscape scale as 100 ha, and this certainly includes the core area for most owls and provides information about breeding habitat across a wider area. At this scale, buffer overlap of some ARUs was unavoidable; however, overlap is consistent with results of field studies in the Northern Rocky Mountains, USA where 50\% overlap of Boreal Owl territories was observed (Hayward et al. 1993).

We quantified the extent of human disturbance at our survey sites as percent area disturbed by the following three different human activities: industrial disturbances, hard linear, and soft linear features. Industrial disturbances included urban and rural industrial sites, mines, borrow pits, well sites, and wind generation sites. We considered landscape alterations resulting from these disturbances to be the most severe because they resulted in permanent loss of forested land and the potential loss of suitable hunting grounds for owls. We divided linear features in two categories: hard linear features (with impermeable surfaces like roads, railways, and runways), and soft linear features (with vegetated surfaces including transmission lines, pipelines, seismic lines, trails, and vegetated verges of roads). Hard linear surfaces are not suitable for owl foraging, fragment the landscape, and negatively affect owls (Boves and Belthoff 2012, Silva et al. 2012). Soft linear features may generate hunting opportunities for owls because they create grassy habitat favored by meadow voles (Microtus pennsylvanicus; Darling 2008), but at high densities can contribute to habitat fragmentation (Pattison et al. 2016), and fragmentation of forested habitats has negative effects on reproductive success of Northern Saw-whet Owls (Hinam and St. Clair 2008).

Incorporating biotic interactions into models improves predictions of owl distributions at certain scales (Heikkinen et al. 2007). In this study, we considered the presence/absence of nesting facilitators, competitors, and potential predators as potential predictors. We analyzed Pileated Woodpeckers as facilitators of owl nesting because both Boreal and Northern Saw-whet Owls breed almost exclusively in cavities created by primary cavity excavators (Hayward et al. 1993, Johnsgard 2002, Korpimäki and Hakkarainen 2012). We also modeled interspecific competition as the presence of Boreal and Northern Saw-whet Owls at the same site, because these owls potentially compete for nest sites and prey. Interactions within the nocturnal predator guild can alter spatial distribution of owls (Kajtoch et al. 2016, Morosinotto et al. 2017); however, there are few published accounts of competition between our study species (but see Lane 1991). Although reports of direct predation of larger owls on smaller owls are rare, diet studies have reported smaller owls, including Northern Saw-whet Owls, as prey items for Great Horned Owls (reviewed by Cromrich et al. 2002). In Finland, the presence of Ural Owls (Strix uralensis) influenced habitat use by Boreal Owls (Korpimäki and Hakkarainen 2012), and in the agriculturally fragmented landscape of central Alberta, patch selection of
Northern Saw-whet Owls was influenced by the presence of Great Horned Owls (Grossman et al. 2008). Thus, we included the presence/absence of Great Horned Owls as an indicator of potential predator pressure in our models.

\section{Analysis}

For data analysis we chose a machine learning technique because it is in contrast to traditional model fitting where the parameters are often estimated based on the assumption of linear and additive relationships, e.g., logistic regression. The approach we used assumes that the relationships between predictor and response variables are complex and determines the relative importance of different predictors by including nonlinear and interactive relationships as well as validating the models (Elith et al. 2008). Boosted regression trees are becoming more popular for modeling species distribution and habitat selection. For example, they have been successfully used to model the distribution of New Zealand's diadromous and nondiadromous fish species (Leathwick et al. 2008), to identify habitat associations of wintering Great Bustards (Otis tarda dybowskii) in China (Mi et al. 2014), and to predict rare species distribution in undersampled areas (Mi et al. 2017).

Specifically, we modeled the distribution of both owl species using boosted regression trees (BRT) implemented using the $\mathrm{gbm}$ (Version 2.1.3, Ridgeway 2007) and dismo (Version 1.1-4, Hijmans et al. 2017) packages in $\mathrm{R}$ ( $\mathrm{R}$ Core Team 2015). A 10-fold cross validation method (Elith et al. 2008) was used to identify metaparameter (De'ath 2007) settings, to build models, and make predictions across the region. Final BRT model settings used a bagging fraction of 0.5 , and a learning rate of 0.005 to build at least 1000 trees (Elith et al. 2008) and allowed complex interactions among predictors using a tree complexity of 5 .

To test the influence of landscape features, climate, and biotic interactions on owl distribution, we first built a global model containing all predictors, and then fit additional models by successively eliminating the climatic, disturbance, and biotic parameters. Models were compared for their predictive capacity using the area under the receiver operating characteristic curve (AUC) and predictive deviance, i.e., variation explained, of the model (Elith et al. 2008). We used a simplification function (Elith et al. 2008) to identify and eliminate variables that did not improve model prediction. We examined the relative importance of predictor variables, visualized effects of selected variables using fitted functions in partial dependency plots, and created maps of spatial distribution of predictions using outputs generated by the final BRT model.

For spatial prediction, we used ArcMap to create a grid of $1 \mathrm{~km}$ $\mathrm{x} 1 \mathrm{~km}(100 \mathrm{ha})$ squares over the boreal region of Alberta. This scale seemed reasonable to accommodate core areas of potentially breeding owls and to allow identification habitats with high probability for use by owls. Information about predictor variables retained in the final model were compiled as discussed above, using the centroids for each square, and used to create raster maps for each predictor. No predictions were made for squares with their centroids outside the Alberta Boreal boundary. Raster layers then were combined into a raster brick, imported into $\mathrm{R}$, and the overall model was used to predict values for each raster cell. These results were exported and visualized in ArcMap. 


\section{RESULTS}

We analyzed acoustic recordings from ARUs deployed at 677 sites, detecting Boreal Owls at 263 sites $(39 \%)$, Northern Saw-whet Owls at 103 sites (15\%), and both species at 38 sites ( $5 \%)$. Although Great Horned Owls were detected at $54 \%$ of the sites and Pileated Woodpeckers were present at $40 \%$ of the sites, biotic components did not improve accuracy of model predictions and the final distribution models included only climatic, disturbance, and landscape variables for both species. Predictive deviance of models was quite similar for both Boreal Owls (36.2\%) and Northern Saw-whet Owls (39.2\%). Similar prediction accuracy was achieved by models for both Northern Saw-whet Owls (AUC $=0.893)$ and Boreal Owls $(\mathrm{AUC}=0.880)$. The top 10 predictors included in final models for both species included seven climatic variables and three variables related to vegetation cover and human disturbance. Precipitation as snow, mean annual precipitation, average winter precipitation, and mean annual temperature were also retained in the final models for both species.

The strongest variable influencing Boreal Owl distribution was average minimum winter temperature (Fig. 2), which contributed $24.4 \%$ to the model predictions and together with four additional climatic variables made a total contribution of $50 \%$ to the final model. Average winter minimum temperatures at sites where Boreal Owls were detected was lower $\left(-21.9^{\circ} \mathrm{C} \pm 0.11^{\circ} \mathrm{C}\right.$; than at unoccupied sites $\left(-20.4^{\circ} \mathrm{C} \pm 0.04\right.$. The most important landscape characteristic predicting Boreal Owl distribution during the breeding season was forest cover at the local scale, while linear features at the landscape scale predicted the spatial distribution of Boreal Owls better than did dominant landcover types at the landscape scale (Fig. 2). Occupied sites had less forest cover $(44.9 \% \pm 2.4)$ than unused sites $(61.4 \% \pm 1.8)$, and used sites had fewer $(2.4 \% \pm 0.2)$ soft linear features than unused sites $(4.1 \%$ $\pm 0.1)$. Boreal Owls were mostly present in areas without croplands or shrub cover (Table 2). Overall, our results indicate that Boreal Owls were mostly present in cool environments with cold winters, and low percent of grassland cover at landscape scale. They were also encountered less in contiguous forests disturbed by soft linear features, and areas where more precipitation falls as snow (Fig. 3). The final model predicting distribution of Boreal Owls (Fig. 4) was strongly influenced by interactions among explanatory variables, and in general reinforced the idea that this species was found mostly in areas characterized by cold winters, offering a combination of forest openings at the local scale and less than $20 \%$ grassland cover at the landscape scale.

Presence of cropland at the landscape scale was the most influential predictor for Northern Saw-whet Owls, and contributed $26.6 \%$ to the final distribution model (Fig. 2). Cropland accounted for $18.6 \% \pm 2.9 \%$ on average (range 0 to $88 \%$ ) of the area within the landscape scale around locations where Northern Saw-whet Owls were detected, while cropland represented only an average of $0.4 \%$ (range $0-91 \%$ ) of the area around unused sites. Important climatic factors predicting Northern Saw-whet Owl distribution included average temperatures both in the warmest and coldest period of the year, as well as precipitation as snow and average summer temperatures (Fig. 2). Northern Saw-whet Owls occupied areas that were more likely to be cooler during summer $\left(15.8^{\circ} \mathrm{C} \pm 0.05^{\circ} \mathrm{C}\right.$ vs. $16.1^{\circ} \mathrm{C}$ $\pm 0.02^{\circ} \mathrm{C}$ ) and slightly warmer during winter than unused sites $\left(-17.0^{\circ} \mathrm{C} \pm 0.2^{\circ} \mathrm{C}\right.$ vs $\left.-18.0^{\circ} \mathrm{C} \pm 0.07^{\circ} \mathrm{C}\right)$. Sites used by Northern Saw-whet Owls had less shrub or grassland cover than unused sites (Table 2). These owls were more likely to occur in areas where cropland was interspersed with deciduous-dominated forests. They were most often found close to forest edges associated with soft linear features, as long as these areas were cool during the summer and had less precipitation as snow (Fig. 5). The predicted distribution of Northern Saw-whet Owls (Fig. 6) highlights environments that offer combinations of cool summers, reduced snowfall, located in forested landscapes with at least $20 \%$ cropland at the landscape scale as being most suitable for this species.

Fig. 2. Relative influence $(\%)$ of predictor variables in the final boosted regression tree model explaining distribution of (a) Boreal Owl (Aegolius funereus) and (b) Northern Saw-whet Owl (Aegolius acadicus) in the Boreal Forest Natural Region of Alberta, Canada. Models were developed using 10-fold crossvalidation on data from 677 sites, with a learning rate of 0.005 and tree complexity of 5 . Final models were achieved using a stepwise simplification process, where variables that did not contribute to improve prediction were eliminated. For explanation of variables see Table 1.

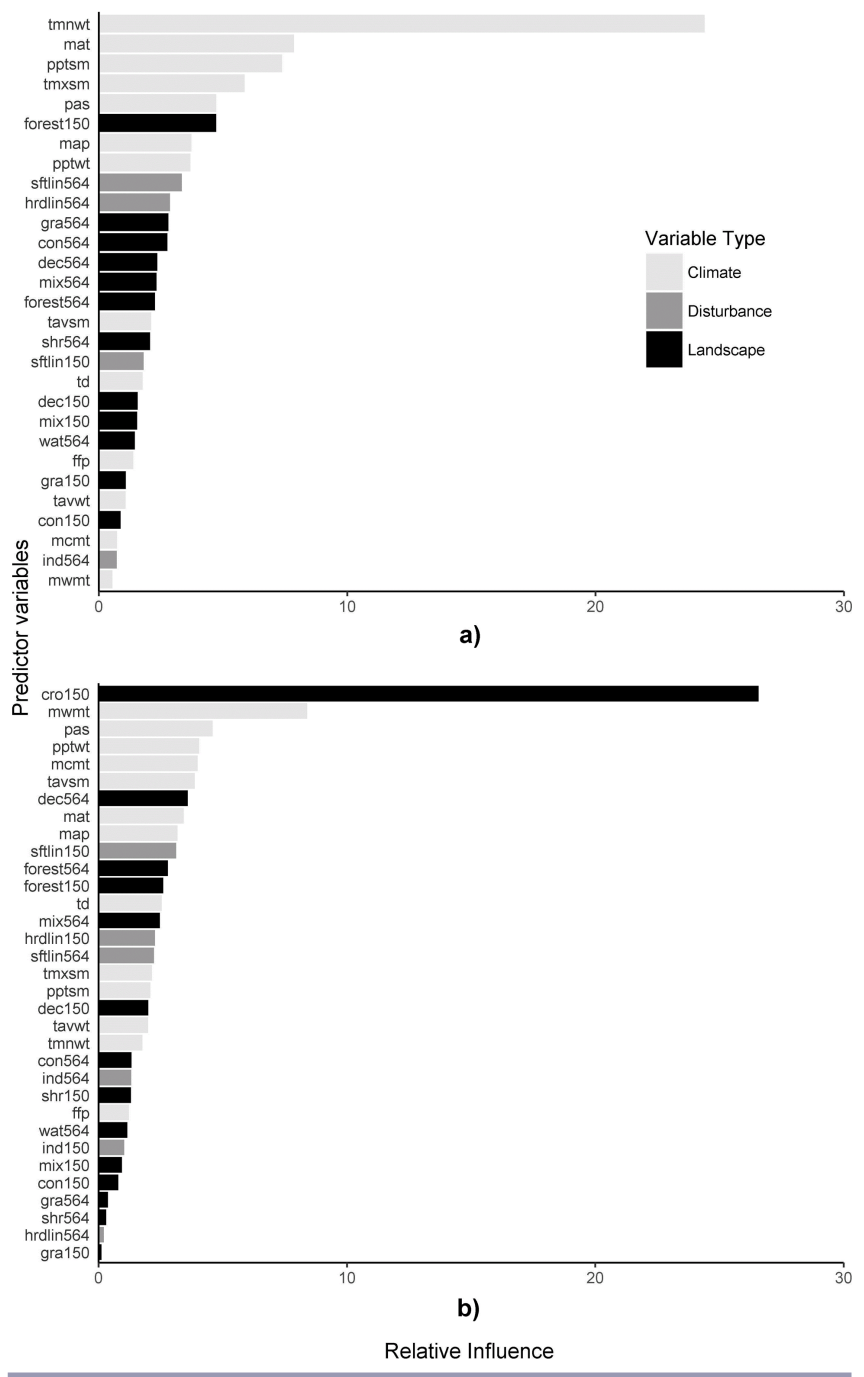


Table 2. Comparison of sites occupied by Boreal Owls (Aegolius funereus) and Northern Saw-whet Owls (Aegolius acadicus) versus unoccupied sites. The values represent averages of climate, landscape, and human disturbance predictor variables used to model their spatial distribution within the Boreal Forest Natural Region of Alberta, Canada. For explanation of variables see Table 1.

\begin{tabular}{|c|c|c|c|c|}
\hline \multirow[t]{2}{*}{ Variable code } & \multicolumn{2}{|c|}{ Boreal Owl } & \multicolumn{2}{|c|}{ Northern Saw-whet Owl } \\
\hline & Unoccupied & Occupied & Unoccupied & Occupied \\
\hline $\operatorname{con} 150$ & 23.1 & 13.4 & 20.3 & 14.0 \\
\hline $\operatorname{con} 564$ & 22.4 & 12.5 & 19.5 & 13.2 \\
\hline cro 150 & 4.0 & 1.0 & 0.3 & 17.0 \\
\hline cro564 & 4.4 & 1.1 & 0.4 & 18.7 \\
\hline $\operatorname{dec} 150$ & 27.7 & 14.9 & 21.5 & 29.1 \\
\hline $\operatorname{dec} 564$ & 27.8 & 18.9 & 23.5 & 29.2 \\
\hline for 150 & 61.4 & 44.9 & 55.8 & 50.8 \\
\hline for 564 & 61.2 & 49.5 & 57.2 & 53.9 \\
\hline $\operatorname{gra} 150$ & 8.3 & 4.4 & 7.2 & 4.7 \\
\hline gra564 & 7.9 & 3.4 & 6.4 & 4.5 \\
\hline $\operatorname{mix} 150$ & 9.0 & 7.4 & 9.0 & 5.0 \\
\hline $\operatorname{mix} 564$ & 9.5 & 7.6 & 8.8 & 8.8 \\
\hline $\operatorname{shr} 150$ & 8.2 & 3.6 & 6.5 & 5.8 \\
\hline $\operatorname{shr} 564$ & 9.0 & 3.0 & 7.2 & 3.6 \\
\hline wat150 & 1.6 & 1.4 & 1.5 & 1.8 \\
\hline wat564 & 2.1 & 1.8 & 2.0 & 1.9 \\
\hline hrdlin 150 & 0.4 & 0.3 & 0.3 & 0.8 \\
\hline hrdlin564 & 0.4 & 0.2 & 0.3 & 0.5 \\
\hline ind 150 & 2.2 & 1.8 & 2.0 & 2.1 \\
\hline ind 564 & 2.5 & 1.6 & 2.4 & 1.0 \\
\hline sftlin 150 & 6.1 & 4.6 & 5.4 & 6.4 \\
\hline sftlin 564 & 4.1 & 2.4 & 3.5 & 3.1 \\
\hline $\mathrm{ffp}$ & 103.6 & 101.2 & 102.8 & 101.9 \\
\hline map & 501.2 & 461.5 & 488.8 & 468.9 \\
\hline mat & 0.9 & 0.1 & 0.5 & 0.9 \\
\hline $\mathrm{mcmt}$ & -17.1 & -18.8 & -17.9 & -17.0 \\
\hline mwmt & 16.0 & 16.2 & 16.1 & 15.8 \\
\hline pas & 132.3 & 129.0 & 132.8 & 121.0 \\
\hline pptsm & 244.9 & 222.5 & 236.3 & 235.1 \\
\hline pptwt & 65.0 & 61.3 & 63.9 & 61.7 \\
\hline tavsm & 14.8 & 14.9 & 14.9 & 14.7 \\
\hline tavwt & -15.0 & -16.5 & -15.7 & -14.9 \\
\hline $\mathrm{td}$ & 33.1 & 35.0 & 34.0 & 32.8 \\
\hline tmnwt & -20.4 & -21.9 & -21.1 & -20.4 \\
\hline tmxsm & 20.6 & 20.7 & 20.7 & 20.7 \\
\hline
\end{tabular}

\section{DISCUSSION}

Our study shows that climate variables support predictions of the spatial distribution of Boreal and Northern Saw-whet Owls in northern Alberta and, furthermore, provides new information for predicting the potential distribution of these owls at a regional scale. Precipitation as snow, mean annual temperature, mean annual precipitation, and average winter precipitation were strong predictors in the final models for both species. Although both winter and summer temperatures were important in the final models, effects differed between the two species. Boreal Owls are mostly present in cooler areas of boreal Alberta, supporting results for this species from the Pyrenees Mountains of Europe where breeding territories are confined to areas where mean January temperatures were between $1{ }^{\circ} \mathrm{C}$ and $-3{ }^{\circ} \mathrm{C}$, and July temperatures
Fig. 3. Partial dependency plots showing the effect of selected climatic, land cover, and human disturbance variables on the distribution of Boreal Owl (Aegolius funereus), after accounting for the average effects of all other variables in the model. Numbers in parentheses show the relative contribution of each variable to the final boosted regression tree model. Y axes are on the logit scale, and the red horizontal lines indicate a marginal effect of zero. For explanation of variables see Table 1.

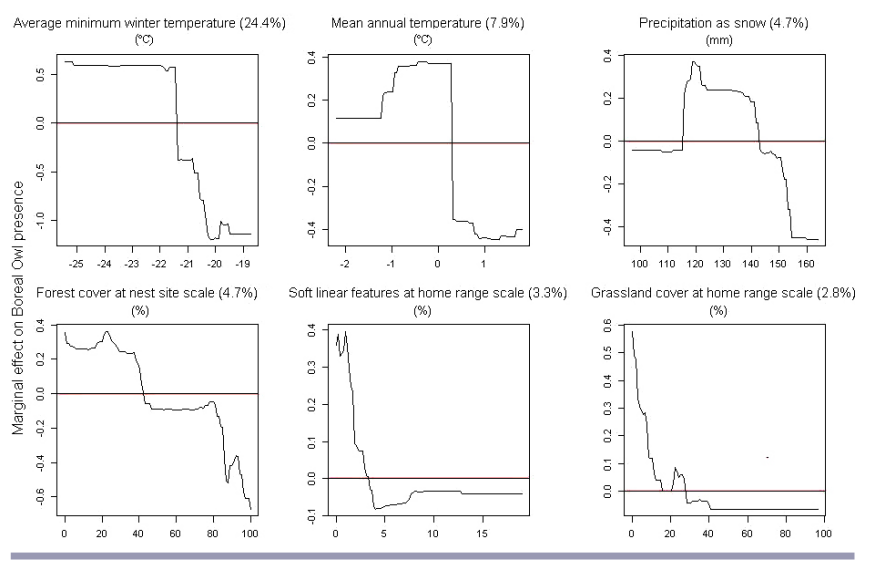

Fig. 4. Predictive breeding distribution of Boreal Owl (Aegolius funereus) in the Boreal Natural Region of Alberta, Canada.

The map resulted from the final boosted regression tree model developed with 29 explanatory variables, including fourth-level interactions among elements of climate, land cover, and human disturbance. Predictions are made at $1 \mathrm{~km}^{2}$ resolution. High probability of occurrence represents areas best suited for Boreal Owls during the breeding season, while low probability of occurrence depicts areas less likely to be used for breeding.

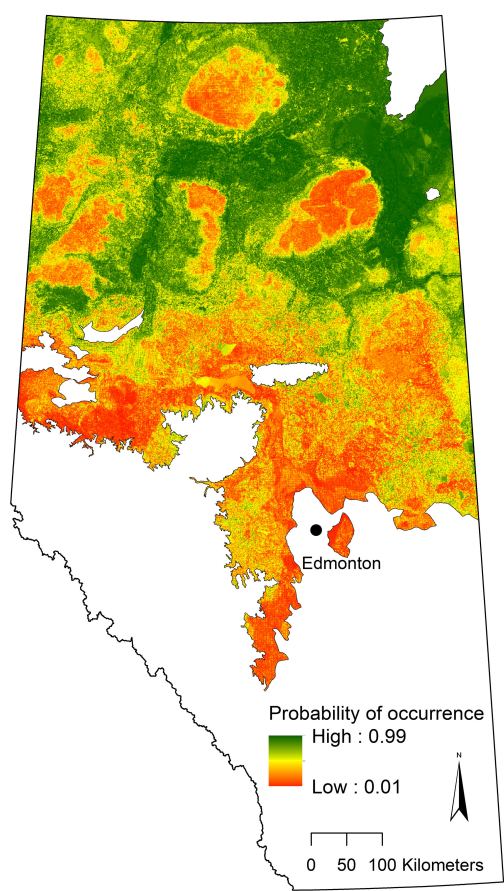


Fig. 5. Partial dependency plots showing the effect of selected climatic, land cover, and human disturbance variables on the distribution of Northern Saw-whet Owl (Aegolius acadicus), after accounting for the average effects of all other variables in the model. Numbers in parentheses show relative contribution of each variable to the final model. Y axes are on the logit scale, and the red horizontal lines indicate a marginal effect of zero. For explanation of variables see Table 1.

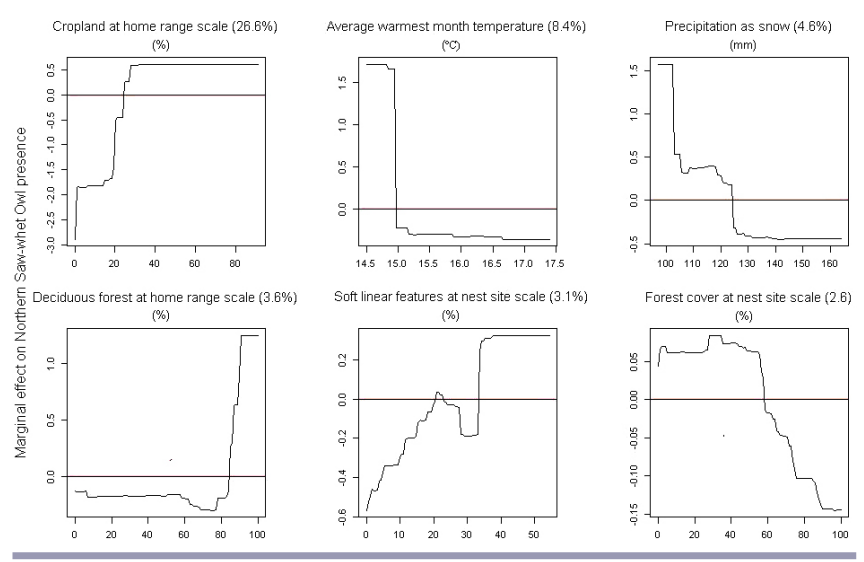

Fig. 6. Predictive breeding distribution of Northern Saw-whet Owl (Aegolius acadicus) in the Boreal Natural Region of Alberta, Canada. The map resulted from the final boosted regression tree model developed with 33 explanatory variables, including fourth-level interactions among elements of climate, land cover, and human disturbance. Predictions are made at 1 $\mathrm{km}^{2}$ resolution. High probability of occurrence represents areas best suited for Northern Saw-whet Owls during the breeding season, while low probability of occurrence depicts areas less likely to be used for breeding.

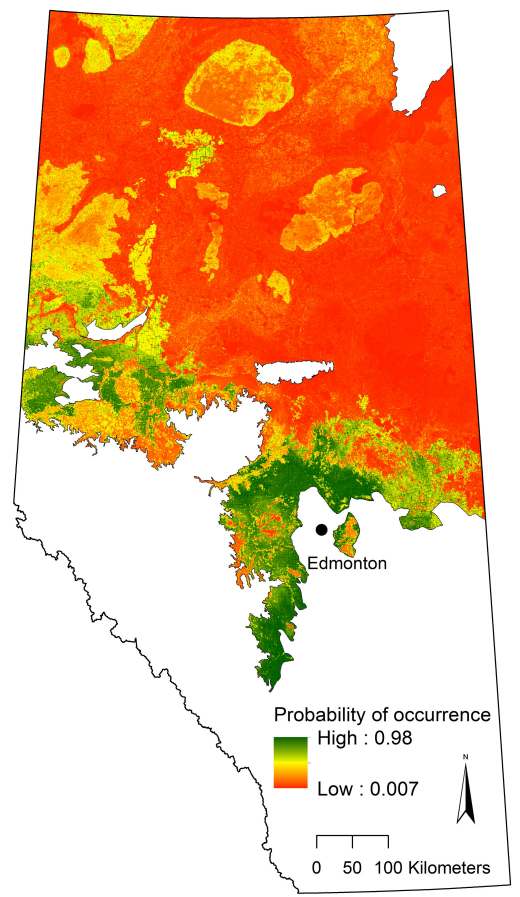

do not exceed $17^{\circ} \mathrm{C}$ (López et al. 2010). We found that Northern Saw-whet Owls are also more commonly found in cool environments, and were consistently present at sites where the average warmest monthly temperature was $<15^{\circ} \mathrm{C}$. This seems to corroborate findings that they may be less able to thermoregulate with rising humidity and ambient temperature (Ligon 1969). Perhaps their distribution is limited by the availability of sites with a cool microclimate, similar to findings for Spotted Owls nesting in hot environments where habitat use is strongly influenced by the availability of cool roost sites created by dense, multilayered canopies (Barrows 1981). Climate is important in shaping distributions of birds of prey at regional or continental scales (Heikkinen et al. 2007, Castro et al. 2008, Brambilla et al. 2013). Data from climate stations in western Canada document temperature increases of $2-4{ }^{\circ} \mathrm{C}$ in the past 40 years with forecasts predicting winter temperature increases of 4- $6{ }^{\circ} \mathrm{C}$ (Schindler and Lee 2010). Thus, our predictive maps could influence management and conservation of the two owl species in boreal Alberta by anticipating possible range shifts and providing information to land and resource managers.

The amount of precipitation as snow was another important climatic predictor of distribution for the Boreal Owl and Northern Saw-whet Owl. Boreal Owls are known to breed in areas with deep snow cover elsewhere (Hayward et al. 1993, Korpimäki and Hakkarainen 2012); however, we found that annual precipitation as snow $>140-150 \mathrm{~mm}$ had a negative effect on Boreal Owl presence in our study region. Our results suggest that this species is most commonly found in areas that receive between 115-145 mm precipitation as snow. Northern Saw-whet Owls were more likely to be present in areas where precipitation as snow did not exceed $100-105 \mathrm{~mm}$, and at the local scale, were rarely detected in areas where annual snowfall exceeds $125 \mathrm{~mm}$. Boreal Owl males start breeding early in the spring and many seem to stay close to their former nest sites during the winter (Korpimäki and Hakkarainen 2012) because they are able to capture prey moving both on top and underneath the snow, even by plunging through moderately thick snow layers (Sonerud 1986). In contrast, the Northern Saw-whet Owl is smaller and lighter, more like the Northern Pygmy Owl (Glaucidium gnoma), and likely would be able to catch mainly prey moving only on top of or close to the snow surface (Sonerud 1986). Variation in the amount of precipitation as snow could differentially affect hunting success and ability to catch prey of male owls establishing territories early in the spring.

Both the Boreal and Northern Saw-whet Owls are forest dwelling species, so we expected their distributions to be strongly influenced by forest type and cover. Nonetheless, presence of open nonforested areas was an important predictor of occurrence for both species. Northern Saw-whet Owls were most frequently encountered in landscapes comprising $>80 \%$ deciduous stands, but the presence of croplands embedded in the forested landscape was the most important factor predicting their presence. This highlights the importance of forests within agricultural landscapes as suitable habitat for this species, and is consistent with the observations that Northern Saw-whet Owls are the most common owls in the mixed agricultural-forest landscape of central Alberta (Grossman et al. 2008). Furthermore, it reinforces the generality of work in both the Sierra Nevada, USA (Groce and Morrison 2010) and southern Idaho (Scholer et al. 2014) 
where occurrence of this species was positively correlated with higher local proportions of open habitat. Data for the Boreal Owl paint a somewhat different picture with similar themes. The only landscape component present among the top-10 predictors was amount of forest at the local scale. Although Boreal Owl was commonly associated with old coniferous forests in our models, studies in Idaho suggest strong selection for some component of aspen stands (Hayward et al. 1993). In addition, our results indicate that grassland cover at the landscape scale appears to be important for the Boreal Owl. We detected them more commonly in areas that included some $(<20 \%)$ permanent grassland, similar to results from northern Italy, where probability of occurrence within a $1 \mathrm{~km}^{2}$ area was positively associated with areas having at least 10\% permanent grassland cover (Brambilla et al. 2013).

Many industrial activities cause habitat destruction and fragmentation of habitats for these owls. Current research suggests that oil and gas exploration and extraction in the western Canadian boreal region has important negative effects on migratory birds (Van Wilgenburg et al. 2013), and seismic lines are the major source of forest fragmentation in the boreal region (Pattison et al. 2016). In our study, linear features appeared to influence owl distribution but with lower relative importance compared to the top predictors for both owl species. Soft linear features were included in $0-19 \%$ of Boreal Owl territories in Alberta, with the model demonstrating that amounts over $4-5 \%$ negatively affect the probability of Boreal Owl occurrence. In contrast, occurrence of Northern Saw-whet Owls was higher in the presence of soft linear features and associated forest edges in the area of potential nest sites. Although soft linear features may be favorable for owls, Silva et al. (2012) showed that hard linear features such as roads increased owl mortality through collisions near high-traffic areas that cross forested habitats. Thus, overall effects of fragmentation are likely to be complicated. Although high levels of fragmentation limited reproductive success of Northern Saw-whet Owls in central Alberta (Hinam and St. Clair 2008), these owls did not avoid areas with soft linear features at the local scale in our study where landscapes were not highly fragmented. Soft linear features in contiguous forested habitats might in fact improve hunting opportunities for Northern Sawwhet Owls (Hayward and Garton 1988). Understanding the details of these relationships is important as increased industrial activity is projected in northern Alberta, including activities that create linear features such as exploration and development of insitu oil sands across more than 4 million hectares (Schindler and Lee 2010).

Both Great Horned Owls and Pileated Woodpeckers were common throughout the study area, but their presence had low relative influence among the considered variables, and did not improve predictive power of the models. Although they were not included in the final models, that does not necessarily mean that predators or nesting facilitators are not important. Being secondary cavity nesters, both Boreal and Northern Saw-whet Owls are dependent on primary cavity excavators (Hayward et al. 1993, Korpimäki and Hakkarainen 2012), and in areas of overlap where many raptor species coexist, predation and interspecific competition might also contribute to spatial distribution (Cody 1985, Rosenzweig 1985, Hayward and Garton 1988). It is quite possible that investigating the influence of predators and nest site providers on owl distribution using only their presence/absence is not adequate and there are other experimental setups that could provide better answers to this question, e.g., predator density, or number of suitable cavities. Our results may reflect the scale at which analyses were conducted because incorporating woodpecker distributions at 10-km scale did improve climate-land cover distribution models of Finnish owls (Heikkinen et al. 2007).

Our study is the first to use the combination of climate, landscape, and human disturbance to predict spatial distribution of Boreal and Northern Saw-whet Owls. Using response variables readily available from geospatial datasets we were able to accurately predict owl distributions and generate maps that predict owl occurrence in remote locations in the boreal region of Alberta. Although both species are associated with forests, the results show that the spatial distributions of both of these small owl species could be affected by both climate change and landscape changes associated with anthropogenic impacts. Temperature increases could result in shifts in distributions as we have seen that both species prefer relatively cool environments. Should such shifts occur, we hold that predictive models like ours will be the right tool to forecast where these owls might potentially go. These predictive models could be applied, for example, in development of Forest Management Plans or Spatial Harvest Sequences. Maps created based on these models could ensure that during the planning process placement of retention forest patches are sited in areas with high probability of occurrence of these owls while considering the cumulative effects of climate, landscape, and human disturbance. In summary, this paper contributes new information on two understudied species that will likely be influenced by the rapid changes occurring in the boreal forests of Alberta. We show that by combining elements of climate, landscape, and human disturbance at various scales, the models developed here, although not without limitations, are capable of predicting owl distributions in a dynamic landscape to assist wildlife and natural resource managers in tracking their populations, and in identifying priority areas for future research and conservation.

Responses to this article can be read online at: http://www.ace-eco.org/issues/responses.php/1445

\section{LITERATURE CITED}

Barrows, C. W. 1981. Roost selection by Spotted Owls: an adaptation to heat stress. Condor 83:302-309. https://doi. org/10.2307/1367496

Block, W. M., and L. A. Brennan. 1993. The habitat concept in ornithology. Theory and applications. Current Ornithology 11:35-91. https://doi.org/10.1007/978-1-4757-9912-5_2

Bondrup-Nielsen, S. 1984. Vocalizations of the Boreal Owl Aegolius funereus richardsoni, in North America. Canadian FieldNaturalist 98:191-197.

Boves, T. J., and J. R. Belthoff. 2012. Roadway mortality of barn owls in Idaho, USA. Journal of Wildlife Management 76:1381-1392. https://doi.org/10.1002/jwmg.378

Brambilla, M., E. Bassi, V. Bergero, F. Casale, M. Chemollo, R. Falco, V. Longoni, F. Saporetti, E. Viganò, and S. Vitulano. 2013. 
Modelling distribution and potential overlap between Boreal Owl Aegolius funereus and Black Woodpecker Dryocopus martius: implications for management and monitoring plans. Bird Conservation International 23:502-511. https://doi.org/10.1017/ S0959270913000117

Buckland, S. T., and D. A. Elston. 1993. Empirical models for the spatial distribution of wildlife. Journal of Applied Ecology 30:478-495. https://doi.org/10.2307/2404188

Campos-Cerqueira, M., and T. M. Aide. 2016. Improving distribution data of threatened species by combining acoustic monitoring and occupancy modelling. Methods in Ecology and Evolution 7:1340-1348. https://doi.org/10.1111/2041-210X.12599

Carey, A. B., J. A. Reid, and S. P. Horton. 1990. Spotted Owl home range and habitat use in southern Oregon coast ranges. Journal of Wildlife Management 54:11-17. https://doi. org/10.2307/3808894

Castro, A., A. R. Munoz, and R. Real. 2008. Modelling the spatial distribution of the Tengmalm's Owl Aegolius funereus in its Southwestern Palearctic limit (NE Spain). Ardeola 55:71-85.

Chen, I. C., J. K. Hill, R. Ohlemuller, D. B. Roy, and C. D. Thomas. 2011. Rapid range shifts of species associated with high levels of climate warming. Science 333:1024-1026. https://doi.org/10.1126/ science. 1206432

Cody, M. L. 1985. An introduction to habitat selection in birds. Pages 4-58 in M. L. Cody, editor. Habitat selection in birds. Academic Press, Orlando, Florida, USA.

Cromrich, L. A., D. W. Holt, and S. M. Leasure. 2002. Trophic niche of North American Great Horned Owls. Journal of Raptor Research 36:58-65.

Darling, A. F. 2008. Linear feature effects on small mammal abundance and resources in the Boreal forest. Thesis. University of Alberta, Edmonton, Alberta, Canada.

De'ath, G. 2007. Boosted trees for ecological modeling and prediction. Ecology 88:243-251. https://doi.org/10.1890/0012-9658 (2007)88[243:BTFEMA]2.0.CO;2

De'ath, G., and K. E. Fabricius. 2000. Classification and regression trees: a powerful yet simple technique for ecological data analysis. Ecology 81:3178-3192. https://doi.org/10.1890/0012-9658 (2000)081[3178:CARTAP]2.0.CO;2

Di Vittori, M., and P. López-López. 2014. Spatial distribution and breeding performance of Golden Eagles Aquila chrysaetos in Sicily: implications for conservation. Acta Ornithologica 49:33-45. https://doi.org/10.3161/000164514X682878

Dunn, E. H., C. M. Francis, P. J. Blancher, S. R. Drennan, M. A. Howe, D. Lepage, C. S. Robbins, K. V. Rosenberg, J. R. Sauer, and A. G. Smith. 2005. Enhancing the scientific value of the Christmas Bird Count. Auk 122:338-346. https://doi.org/10.1093/ auk/122.1.338

Elith, J., C. H. Graham, R. P. Anderson, M. Dudik, S. Ferrier, A. Guisan, R. J. Hijmans, F. Huettmann, J. R. Leathwick, A. Lehmann, J. Li, et al. 2006. Novel methods improve prediction of species' distributions from occurrence data. Ecography 29:129-151. https://doi.org/10.1111/j.2006.0906-7590.04596.x
Elith, J., J. R. Leathwick, and T. Hastie. 2008. A working guide to boosted regression trees. Journal of Animal Ecology 77:802-813. https://doi.org/10.1111/j.1365-2656.2008.01390.x

Folliard, L. B., K. P. Reese, and L. V. Diller. 2000. Landscape characteristics of Northern Spotted Owl nest sites in managed forests of northwestern California. Journal of Raptor Research 34:75-84.

Gill, M., and R. J. Cannings. 1997. Habitat selection of Northern Saw-whet Owls (Aegolius acadicus brooksi) on the Queen Charlotte Islands, British Columbia. Biology and Conservation of Owls of the Northern Hemisphere 190:197-204.

Groce, J. E., and M. L. Morrison. 2010. Habitat use by Saw-whet Owls in the Sierra Nevada. Journal of Wildlife Management 74:1523-1532. https://doi.org/10.1111/j.1937-2817.2010.tb01280. $\mathrm{X}$

Grossman, S. R., S. J. Hannon, and A. Sánchez-Azofeifa. 2008. Responses of Great Horned Owls (Bubo virginianus), Barred Owls (Strix varia), and Northern Saw-whet Owls (Aegolius acadicus) to forest cover and configuration in an agricultural landscape in Alberta, Canada. Canadian Journal of Zoology 86:1165-1172. https://doi.org/10.1139/Z08-095

Guisan, A., R. Tingley, J. B. Baumgartner, I. Naujokaitis-Lewis, P. R. Sutcliffe, A. I. T. Tulloch, T. J. Regan, L. Brotons, E. McDonald-Madden, C. Mantyka-Pringle, et al. 2013. Predicting species distributions for conservation decisions. Ecology Letters 16:1424-1435. https://doi.org/10.1111/ele.12189

Harms, T. M., K. T. Murphy, X. D. Lyu, S. S. Patterson, K. E. Kinkead, S. J. Dinsmore, and P. W. Frese. 2017. Using landscape habitat associations to prioritize areas of conservation action for terrestrial birds. PLOS ONE 12(3):e0173041. https://doi org/10.1371/journal.pone.0173041

Haug, E. A., and L. W. Oliphant. 1990. Movements, activity patterns, and habitat use of Burrowing Owls in Saskatchewan. Journal of Wildlife Management 54:27-35. https://doi. org/10.2307/3808896

Hayward, G. D. 1997. Forest management and conservation of Boreal Owls in North America. Journal of Raptor Research 31:114-124.

Hayward, G. D., and E. O. Garton. 1988. Resource partitioning among forest owls in the River of No Return Wilderness, Idaho. Oecologia 75:253-265. https://doi.org/10.1007/BF00378606

Hayward, G. D., P. H. Hayward, and E. O. Garton. 1993. Ecology of Boreal Owls in the Northern Rocky Mountains, USA. Wildlife Monographs:1-59.

Heikkinen, R. K., M. Luoto, R. Virkkala, R. G. Pearson, and J. H. Korber. 2007. Biotic interactions improve prediction of boreal bird distributions at macro-scales. Global Ecology and Biogeography 16:754-763. https://doi.org/10.1111/j.1466-8238.2007.00345. $\mathrm{x}$

Hijmans, R. J., S. Phillips, J. R. Leathwick, and J. Elith. 2017. dismo: Species distribution modeling. $\mathrm{R}$ package version 1.1-4. [online] URL: https://cran.r-project.org/package=dismo 
Hinam, H. L., and C. C. St. Clair. 2008. High levels of habitat loss and fragmentation limit reproductive success by reducing home range size and provisioning rates of Northern saw-whet owls. Biological Conservation 141:524-535. https://doi.org/10.1016/ j.biocon.2007.11.011

Johnsgard, P. A. 2002. North American owls: biology and natural history. Second edition. Smithsonian Institution Press, Washington, D.C., USA.

Kajtoch, Ł., M. Matysek, and T. Figarski. 2016. Spatio-temporal patterns of owl territories in fragmented forests are affected by a top predator (Ural owl). Annales Zoologici Fennici 53:165-174. https://doi.org/10.5735/086.053.0405

Kinstler, K. A. 2009. Great Horned Owl Bubo virginianus vocalizations and associated behaviours. Ardea 97:413-420. https://doi.org/10.5253/078.097.0403

Kirk, D. A., and C. Hyslop. 1998. Population status and recent trends in Canadian raptors: a review. Biological Conservation 83:91-118. https://doi.org/10.1016/S0006-3207(97)00051-7

Kissling, M. L., S. B. Lewis, and G. Pendleton. 2010. Factors influencing the detectability of forest owls in Southeastern Alaska. Condor 112:539-548. https://doi.org/10.1525/cond.2010.090217

Korpimäki, E., and H. Hakkarainen. 2012. The Boreal Owl: ecology, behaviour and conservation of a forest-dwelling predator. Cambridge University Press, New York, New York, USA. https:// doi.org/10.1017/CBO9780511844164

Lane, B. 1991. Physical interaction between a male boreal owl and male Northern Saw-whet Owl. Loon 63:74-75.

Leathwick, J. R., J. Elith, W. L. Chadderton, D. Rowe, and T. Hastie. 2008. Dispersal, disturbance and the contrasting biogeographies of New Zealand's diadromous and nondiadromous fish species. Journal of Biogeography 35:1481-1497. https://doi.org/10.1111/j.1365-2699.2008.01887.x

Lehmkuhl, J. F., and M. G. Raphael. 1993. Habitat pattern around Northern Spotted Owl locations on the Olympic Peninsula, Washington. Journal of Wildlife Management 57:302-315. https:// doi.org/10.2307/3809427

Ligon, J. D. 1969. Some aspects of temperature relations in small owls. Auk 86:458-472. https://doi.org/10.2307/4083408

López, B. C., D. Potrony, A. López, E. Badosa, A. Bonada, and R. Saló. 2010. Nest-box use by Boreal Owls (Aegolius funereus) in the Pyrenees mountains in Spain. Journal of Raptor Research 44:40-49. https://doi.org/10.3356/JRR-09-32.1

López-López, P., C. García-Ripollés, J. M. Aguilar, F. GarciaLópez, and J. Verdejo. 2006. Modelling breeding habitat preferences of Bonelli's Eagle (Hieraaetus fasciatus) in relation to topography, disturbance, climate and land use at different spatial scales. Journal of Ornithology 147:97-106. https://doi. org/10.1007/s10336-005-0019-3

MacArthur, R. H. 1972. Geographical ecology: patterns in the distribution of species. Princeton University Press, Princeton, New Jersey, USA.

Mbogga, M. S., H. C., T. Wang, and A. Hamann. 2010. A comprehensive set of interpolated climate data for Alberta. Alberta
Sustainable Resource Development Publication Number: Ref. T/235. Government of Alberta, Edmonton, Alberta, Canada. ISBN: 978-0-7785-9184-9.

Mi, C. R., F. Huettmann, and Y. M. Guo. 2014. Obtaining the best possible predictions of habitat selection for wintering Great Bustards in Cangzhou, Hebei Province with rapid machine learning analysis. Chinese Science Bulletin 59:4323-4331. https:// doi.org/10.1007/s11434-014-0445-9

Mi, C., F. Huettmann, Y. Guo, X. Han, and L. Wen. 2017. Why choose Random Forest to predict rare species distribution with few samples in large undersampled areas? Three Asian crane species models provide supporting evidence. PeerJ 5:e2849. https://doi.org/10.7717/peerj.2849

Morosinotto, C., A. Villers, R. L. Thomson, R. Varjonen, and E. Korpimäki. 2017. Competitors and predators alter settlement patterns and reproductive success of an intraguild prey. Ecological Monographs 87:4-20. https://doi.org/10.1002/ecm.1238

Muñoz, A. R., and R. Real. 2013. Distribution of Bonelli's Eagle Aquila fasciata in southern Spain: scale may matter. Acta Ornithologica 48:93-101. https://doi.org/10.3161/000164513X670043

Muñoz, A. R., R. Real, A. M. Barbosa, and J. M. Vargas. 2005. Modelling the distribution of Bonelli's Eagle in Spain: implications for conservation planning. Diversity and Distributions 11:477-486. https://doi.org/10.1111/j.1366-9516.2005.00188. $\mathrm{x}$

National Regions Committee. 2006. Natural regions and subregions of Alberta. Compiled by D. J. Downing and W. W. Pettapiece. Pub. No. T/852. Government of Alberta, Edmonton, Alberta, Canada. https://doi.org/10.5962/bhl.title.115367

Osborne, P. E., J. C. Alonso, and R. G. Bryant. 2001. Modelling landscape-scale habitat use using GIS and remote sensing: a case study with Great Bustards. Journal of Applied Ecology 38:458-471. https://doi.org/10.1046/j.1365-2664.2001.00604.x

Palmer, D. A. 1987. Habitat selection, movements and activity of boreal and Saw-whet Owls. Raptor Research 21:45-45.

Pattison, C. A., M. S. Quinn, P. Dale, and C. P. Catterall. 2016. The landscape impact of linear seismic clearings for oil and gas development in Boreal forest. Northwest Science 90:340-354. https://doi.org/10.3955/046.090.0312

R Core Team. 2015. R: A language and environment for statistical computing. R Foundation for Statistical Computing, Vienna, Austria. [online] URL: https://www.R-project.org/

Rabinowitz, D. 1981. Seven forms of rarity. Pages 205-217 in H. Synge, editor. The biological aspects of rare plant conservation. John Wiley \& Sons, Hoboken, New Jersey, USA.

Rasmussen, J. L., S. G. Sealy, and R. J. Cannings. 2008. Northern Saw-whet Owl (Aegolius acadicus), version 2.0. In A. F. Poole, editor. The birds of North America. Cornell Lab of Ornithology, Ithaca, New York, USA. https://doi.org/10.2173/bna.42

Ridgeway, G. 2007. Generalized boosted models: a guide to the gbm package.

Rosenzweig, M. L. 1985. Some theoretical aspects of habitat selection. Pages 517-540 in M. L. Cody, editor. Habitat selection in birds. Academic Press, Orlando, Florida, USA. 
Rushton, S. P., S. J. Ormerod, and G. Kerby. 2004. New paradigms for modelling species distributions? Journal of Applied Ecology 41:193-200. https://doi.org/10.1111/j.0021-8901.2004.00903.x

Sauer, J. R., W. A. Link, J. E. Fallon, K. L. Pardieck, and D. J. Ziolkowski, Jr. 2013. The North American Breeding Bird Survey 1966-2011: summary analysis and species accounts. North American Fauna 79:1-32. https://doi.org/10.3996/nafa.79.0001

Saurola, P. 2009. Bad news and good news: population changes of Finnish owls during 1982-2007. Ardea 97:469-482. https://doi. org/10.5253/078.097.0411

Schindler, D. W., and P. G. Lee. 2010. Comprehensive conservation planning to protect biodiversity and ecosystem services in Canadian boreal regions under a warming climate and increasing exploitation. Biological Conservation 143:1571-1586. https://doi.org/10.1016/j.biocon.2010.04.003

Scholer, M. N., M. Leu, and J. R. Belthoff. 2014. Factors associated with Flammulated Owl and Northern Saw-whet Owl occupancy in southern Idaho. Journal of Raptor Research 48:128-141. https://doi.org/10.3356/JRR-13-00049.1

Shonfield, J., and E. M. Bayne. 2017a. Autonomous recording units in avian ecological research: current use and future applications. Avian Conservation and Ecology 12(1):14. https:// doi.org/10.5751/ace-00974-120114

Shonfield, J., and E. M. Bayne. 2017b. The effect of industrial noise on owl occupancy in the boreal forest at multiple spatial scales. Avian Conservation and Ecology 12(2):13. https://doi. org/10.5751/ace-01042-120213

Shonfield, J., S. Heemskerk, and E. M. Bayne. 2018. Utility of automated species recognition for acoustic monitoring of owls. Journal of Raptor Research 52:42-55. https://doi.org/10.3356/ JRR-17-52.1

Silva, C. C., R. Lourenço, S. Godinho, E. Gomes, H. SabinoMarques, D. Medinas, V. Neves, C. Silva, J. E. Rabaça, and A. Mira 2012. Major roads have a negative impact on the Tawny Owl Strix aluco and the Little Owl Athene noctua populations. Acta Ornithologica 47:47-54. https://doi.org/10.3161/000164512X653917

Sonerud, G. A. 1986. Effect of snow cover on seasonal changes in diet, habitat, and regional distribution of raptors that prey on small mammals in boreal zones of Fennoscandia. Ecology 9:33-47. https://doi.org/10.1111/j.1600-0587.1986.tb01189.x

Takats, D. L., C. M. Francis, G. L. Holroyd, J. R. Duncan, K. M. Mazur, R. J. Cannings, W. Harris, and D. Holt. 2001. Guidelines for nocturnal owl monitoring in North America. Beaverhill Bird Observatory and Bird Studies Canada, Edmonton, Alberta, Canada.

Tremain, S. B., K. A. Swiston, and D. J. Mennill. 2008. Seasonal variation in acoustic signals of Pileated Woodpeckers. Wilson Journal of Ornithology 120:499-504. https://doi.org/10.1676/07-137.1
Van Wilgenburg, S. L., K. A. Hobson, E. M. Bayne, and N. Koper. 2013. Estimated avian nest loss associated with oil and gas exploration and extraction in the western Canadian sedimentary basin. Avian Conservation and Ecology 8(2):9. https://doi. org/10.5751/ACE-00585-080209

Young, N. E., T. J. Stohlgren, P. H. Evangelista, S. Kumar, J. Graham, and G. Newman. 2012. Regional data refine local predictions: modeling the distribution of plant species abundance on a portion of the central plains. Environmental Monitoring and Assessment 184:5439-5451. https://doi.org/10.1007/s10661-011-2351-9

Zuberogoitia, I., J. Zabala, and J. E. Martínez. 2011. Bias in little owl population estimates using playback techniques during surveys. Animal Biodiversity and Conservation 34:395-400.
Editor-in-Chief: Ryan Norris

Subject Editor: Jean-Pierre L.Savard
Sponsored by the Society of Canadian Ornithologists and Bird Studies Canada Parrainée par la Société des ornithologistes $d u$ Canada et Études d'oiseaux Canada

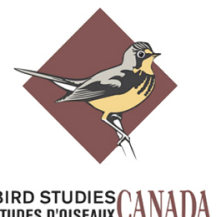

